\title{
A Thematic Content Analysis Concerning the Emotional Message Repertory of the TV Commercials of the Products Directed at the Young Target Audience
}

\author{
Uğur Batı, Yeni Yüzyıl University, Turkey \\ Bünyamin Atıcı, Fırat University, Turkey
}

\begin{abstract}
The purpose of this study is to reveal the emotional message repertory in the television commercials directed at the young target audience. A content analysis is realized in the coverage of the study. The content analysis is used in the study. Total 2482 commercial spots, which are broadcasted in the prime time hours in 4 different national channels are recorded. The number of the commercials addressing to the young target audience between them became 1193. It is seen in the study that the commercials directed at the young target audience realized in 9 different categories. 10 different thematic categories are put forward directed at the young people in these 9 categories. The distribution of the mentioned categories to the channels is performed. In addition to this, most repeated 10 commercials are determined in all of the commercials and young commercials and the message contents of these commercials are examined. It is determined that the maximum messages directed at the young people among all of the commercials are in the food and beverage category with 425 single commercials. When it is looked at the thematic distribution, the messages concerning the difference took part in the first place among all of the commercials with 390 commercials.
\end{abstract}

Keywords: commercial, television commercials, young products, emotional commercial message strategies, content analysis 


\section{Introduction}

$22 \%$ of Turkey is composed of the young group between the ages 12-22. The widest age group in the population of Turkey is the age group 15-19. At the same time, this is a valid data not only for men but also for women (Source: TÜİK, 2000 Census). Turkey is one of the countries with the highest young population rate. It is in the second place followed by Mexico at present. According to the population projection, Turkey will be the country with the highest young population rate in the year 2025. This population lives in the urban areas to a considerable extent. The young people live in Marmara and Interior Anatolia region intensively (TUIK). The educational status of the young population is much below the average of the EU countries. While the rate of being at leas high school graduate of the young population in EU is $95.3 \%$, this rate is 41.8 in Turkey (Eurostat, 2005). When we look at the subject in terms of consumption, it is seen that the consciousness of the young people developed in comparison with the previous years at the point of brand in Turkey in which the consumption is higher than production based on the young population, and the influence of the brand preferences within the family reached the highest level in the family.

One of the recent researches of AC Nielsen which is a research corporation presented very important data for the brands in terms of the young people profile in Turkey in connection with this subject (For details see http://www.iaatram.com/downloads/Genclik\%20Arastirmasi.doc). The study which is performed with 1010 persons in five cities may enable us to have some important profile information which puts forward the attitudes and behaviors of the Turkish youth by means of mentioning some carrier returns from these studies. According to this, the first important finding put forward that the Turkish young people make their own decisions. Having sufficient interest and information about all kinds of products and being able to access to the newest information and the increasing sensitivity of their families towards their opinions enable them to place in decision-making position. The study, which is carried out in order to determine what they look for in a brand, the criteria in their brand preferences, changes and tendencies, expressed that this mentioned group keep their expenditures under control, the importance which they attach for dressing is at the high levels and they are closely interested in technology.

Considering the demographic data of Turkey in a more extensive way, we see that $60.9 \%$ of the Turkey population is composed of a mass below the age 35. Another importance of the 
mentioned age group 12-22 is the situation of this target audience as being the mass consumer of the future. It should be remembered that the future of the marketing will be shaped by the young people in some meaning. The new strategies, new products or services and the marketing approaches which will be used in their promotion are shaped in accordance with the tendencies of the young people. Also, we mention here considerably professional consumers with complicated expectations. As different from a lot of adults, a considerable part of the days of the young people is spent with their friends at their age groups. There are school, friend relationships and the last episodes of the Turkish series on the agenda of the young people. The commercials are also among their popular conversation subjects, as well as the subjects such as last music videos of the new generation young soloists. They also separate some part of their times for the positive or negative critiques. We mention here a group of people who express that they could not live without internet, could not recognize the world without cell phones and, so to say, who live the world as offline and online. At this point, the media consumption preferences are very different from their pioneers. The young people are affected again by the young people at most. The influence of friends increases proportionally with the age. The friends start to replace the family in their preferences by means of providing emotional assistance.

The young target audience does not want to be in passive position which the marketing message encodes for them only. They seek interactive marketing environments in which they participate. They also think that the messages of the brands which they use should be creative, surprising, wondering, attractive and provocative (Schmitt, 1999, p. 42). In connection with that point, today a new approach is discussed under the title of experimental marketing in marketing. The young people become effective in creating the brand values by means of using all of the social media, micro blogs and sharing websites effectively in this marketing style which is built in the consumer experiences, stimulates and entertains the consumer and touches the consumer emotionally as well. The relationship with the young people of the word-of-mouth marketing styles which enable the brands to transmit their values on the users, increase the closeness between the user and the brand, reinforce the brand commitment, arose reliance more and more with the consumer and develop the brand experience with the consumer and make the brand privileged in the minds of the consumers is becoming a subject of discussion in the academic environments as well (Godes \& Mayzlin, 2004). 
The companies such as Tuborg, Efes Pilsen, Coca-Cola, Binboamania, Vodafone, ETí, Türk Telekom, TTNet, Alpella and Finansbank appear with the agencies which make marketing only for young people and they try to be in the university campuses for 365 days. They reach 300 thousand university students in 10 provinces in a year with the organization titled "ETİ Fest" which is one of them. Rock'n Dark Express Music Competition, Efes Pilsen Blues Festival and Efes Pilsen One Love which are organized by Efes Pilsen brand which is a famous bear brand, make the young people to have the Efes Pilsen experience for three times in a year. Türk Telekom Group tries to reinforce the perception of young brand by means of the 'FiesTTa' events which are organized in the university campuses. MTV reveals the tendencies of the young people, prepares programs at this direction and established a research team for the purpose of taking more commercials in this manner. The only purpose of the team is to understand the young people. There will be not much chance for the brands which could not approach to the target audiences correctly, do not give them the correct messages and could not be a part of them in the competition-intensive environments of the day. The advertisers have some foresights based on the researches and experiences on this subject. For instance, music and humor are considered two primary factors in order to catch up with the new generation. A lot of studies which have been carried out in recent five years by AC Nielsen indicate the same fact as well. The responses which are given to the question "What kinds of commercials attract your attention most?" by the young people show that the commercial attributes containing the "entertaining" and "smart attract the attention of the young people more. We see that the Telsim, Doritos and Opet commercials in which Cem Y1lmaz featured on different dates of release are still remembered and still on the agenda of the young people. On the other hand, it is also possible to witness that the slogan of "fully emotional" of the past times maintains its penetration among the young people.

As a result, the advertisement provides the people with a lifestyle in accordance with their own approaches. While the commercial messages are presented to the society, it is a form of communication in which sexuality, happiness, grief, homecoming, aspiration, entertainment, guise, adventure and even dark sides of death, namely every part of life are used in a unique flexibility, by means of benefiting from the very broad social and cultural resources, in a manner to persuade the target audience (Rutherford, 2000, p. 17). The commercial texts create a scheme of attitudes for the potential target audience by means of forming or implanting some desired 
behavioral models in this manner. The behaviors of the readers/spectators are standardized in certain forms in these texts. The advertisers also behave very sensitively, while determining the repertory of the message in the products as directed at the young target audience. In this framework, while performing the product/service benefit in the commercials directed at the young target audience, the requests of the target audience are determined and customized in details. The expressions which are transferred from the real life in accordance with the mentioned requests are covered with the symbolic change values belonging to the people and the meaning is assigned to the product promoted. Getting the change value by the commodity is realized in this manner in general in its operational process in the commercials. This expresses the operation process of the commercials as a projective system in brief.

Even if the Turkish literature is not very rich on this subject, there are some studies in the academic literature on the subject of messages directed at the young people in the commercials. However, most of these studies are the studies which examine the messages directed at the young people in the cigarette and alcohol commercials (Collins, et al., 2007, p. 527-534; Jernigan, Ostroff \& Ross, 2005, p. 312-325; Pasch, et al., 2007, p. 587-596; Stacy, Zogg, Unger $\&$ Dent, 2004, p. 498-509). The number of the studies which classify the messages as directed at the young people is very few in the products directed at the young people directly (Brackett \& Carr, 2001, p. 23-32; Cappo, 2003; Spero \& Stone, 2004, p. 153; Thiyagu, 2008). In this study, it will be also tried to determine the thematic categories of the emotional commercial messages which are given as directed at the young people, with a content analysis to be carried out concerning the TV commercials of the products directed at the young people. It is considered that these messages have influence on the individual beings and identity formations of the young people (Fischer \& Arnold, 1994, p. 163-182; Leiss, Kline \& Jhally, 1990; Schroeder, 1998; Williamson, 2000).

\section{Products Directed at the Young Target Audience}

BBDO which is the global agency which implements a project titled Youth Diary 2009 for the purpose of rescuing the creative teams from the cliché youth definitions in the works to be performed presents some valuable implications concerning the young consumers. The study is carried out on a mass of people between the ages 19-24, from ten different universities, from different departments, having different social-economical structures, having different psycho graphical characteristics and different areas of interest and living conditions. The Facebook 
content which is full of photographs, wall posts and event news etc collected from the sample is examined in the study which is taken up by means of the insight method. The study, which started from foresight that placing the young people in a single definition will be a constraint, determined the expectations and areas of interest of the young people and the roles played in the daily life and the consumption habits surrounding these roles are determined under these categories: The first young people category appearing in the study is called philosopher. A philosopher who tries to understand the life and to find his place is matched with the attributes of leader, reliable, coming down to earth and realistic. NTV, Google and Nokia take part among the preferences of this group. The "Good family child" which is the second category is a good family child who proves to be an individual and also fears the individual life and complies with the established rules until he will be on his way. The brands of the good family child are the brands such as Ülker, Eti and Danone which are warm, close protecting and committed to the traditional values. The group, which is called Survivor, is composed of the young people who do not fear defeating, push the limits and know how to overcome the life. The brands of Survivor are the brands such as Ruffles, Adidas and Pepsi which follow the change; develop itself; dynamic and versatile.

The brands of the "artist", which characterizes the young people who have self-confidence, more beautiful, smarter and more skilled than everybody and has the leading role in the life of at least one person, are the brands such as Miller, Marlboro, Cnbc-e and Starbucks which are not easily accessible. The amigos, who hang together, indispensable members of the team, braver while with the friends, more colorful, more entertaining and ready to rise to the bait, prefer to the brands such as Dominos, Carlsberg, Gittigidiyor, and Youtube. These brands, according to this group, are colorful; encourage to share, worth being a part of it and entertaining. A divergent, who is sensitive to what is going on in his surrounding, wants to speak, values to express himself and to be seen by the others, prefer to the brands such as Penguen, Uykusuz, Radikal, Ekşisözlük which are critical, sensitive, visionary and criticize the environment. In addition to this study which interrogates the known clichés on the subject of young people, the sector magazines such as MediaCat make this generation which is called $\mathrm{F}$ Generation the subject of the cover. The consumers of the future put forward interesting data concerning this new generation with their Trendview and Planet Edge studies which are 
performed by Synovate (http://www.egitisim-blog.com/genclere-gore-markalarinkisiselozellikleri-arastirmasi).

Turkey, with its intensive young population, is evaluated as an important market for the international companies as well. The influence of the young target audience on the consumption processes and also on the market share of the brands is a situation which could not be ignored. The young target audience forms a big market in a very wide range with its other special expenses such as dressings, foods, books, school expenditures and entertainment. We see that the differentiations of the young people in their own age group also affect their product preferences. While it is seen that the 12-18 age group mostly prefers to the chocolate and carbonated drinks, the 19-22 age group greatly cares about the product categories such as dressing, fast food and entertainment because of its search for socialization and social acceptance. We also see that these separations influence the message formation of the brands as well. According to the study, the dressing products have the weight in the first five most frequently mentioned brands. At the same time, the young people have some symbol brands. For example, Nike in read made clothes, Nokia in technology could be mentioned for these symbol brands. The brands, which are positioned as product or service as directed at the young people, determine the needs and expectations of the young people with sniper shots and then form their messages accordingly. Today, even the banks, which hare considered as impartial products in terms of their contents, consider the young people as a special category and give special messages for them. For example, Akbank implemented exi26 in order to provide services for the university students and young professionals between the ages 16-26 with its exi26 product. Is Bankasl markets the banking product as directed at the young people with its Is'te Universiteli which it promoted with the slogan "Announce your economical freedom". Garanti Bankası provides services with g'bank for the young people between the ages 12-18 and Unibank for the university students, in the coverage of the "Life Phases Banking". Yapı Kredi also provides the Youth Banking Package under the title Play Club for the young people between the ages 12-17. HSBC presents special services with Campus Card which is used by more than 300.000 university students at present.

The brands consider the marketing for young people as a different category, and then realize the necessary marketing communication formation at the stage of creating the brand values. An important criterion for the brand formations is the situation whether the products and services 
which are presented to the consumers are in compliance with the needs, expectations, pleasures and ways of thinking of the young people. While the brands run after various renovations for the product or service development in compliance with the needs and expectations of the young people, they are encountered with the complicated and multidimensional shopping preferences of the young people as the criteria which will determine whether the brands could address them or not.

\section{Message Strategies and Emotional Commercial Messages Used in the Commercials}

The human brain is a quite pragmatic structure. It arbitrarily selects and takes all kinds of messages received. All of its selections do not exceed 5\% of those exposed in the mentioned process. When we look at the situation from advertisement point of view, it is the indicator that: Even if you manage to enable the target audience to receive the intended message, your chance to get your desires done is $5 \%$ only. In addition to this, there are more complicated processes in question than brand awareness in the brand communication. It is necessary to mention the different consumption motivations such as belonging, identity formation and customization. Creating on the target audience through the brands influences the same. Particularly whenever the young people are in question, it is necessary to say that the situation is much more complicated. Today, a young person who lives in metropolises encounters 10.000 advertisements at average in a day in street, TV, newspaper and internet. And this means that we view approximately 3.5 million of advertisements in a year. We should say that this figure gives the brands a message: how could you attract the attention of the target audience among millions of messages? Let's associate the question with our subject and then ask again: How could we attract the attention of the young people while we perform marketing directed at the young people? What kinds of messages will be more effective on this subject? Well, what do the brands think about that? Around which themes the messages given to the young people in their advertisements get together at this point? The fundamental questions concerning the determination of the message repertory as directed at the young people are seen as aforesaid.

The advertisement message formation is determined by the advertisement creative strategy. It is composed of the selection of the words to be said and the advertisement appearance after examining the factors which determine the advertisement message. However, the advertisement which is performed around a certain strategy attracts more attention reminded and entertains than the other advertisements. The creative strategy process which is shaped 
under the pressure of the internal and external conditions starts with the appearance and development of the creative thinking. The creative process also comprises the emotional dimension as well as the rational dimension and the original opinion requires "grouping the ideas which are inspired from subconscious and managed intuitively in an experimental manner" (Ogilvy, 1989, p. 38). In this meaning, depending on the hard sell and soft sell techniques of the message crated in the advertisement; the messages which are used in the advertisements are divided into two as rational and emotional messages (Baldwin, 1989, p. 8292). While the rational messages indicate an informing type of message with a serious style in general, the emotional messages are divided into sub-groups as the humorous, realistic, musical and exaggerated ways of expression.

While the message elements such as sections from life, problem solving, demonstrations, comparison, news, witness illustrate the rational message types used in the advertisements, the messages are formed in an objective way, directly relating to the product or service advertised in such message formations. The interpretation of these messages is in a characteristic which does not vary from person to person in general with regard to its content. The informational message strategy is to inform the consumers in a correct, realistic and logical way relating to the product and service. In addition to this, in informational advertisement strategy, the messages could be created as comparative (comparison of the product with the rivals), a single sales slogan (presentation of the claims showing the usage benefits of the product), priority (provable claim of being good based on benefit or interest), exaggeration and credits (intensification on the product class) (Laskey et al., 1989, p. 38-39). Apart from the rational messages, the surprising messages are used in order to attract the attention of the consumers and to ensure the participation in the emotional affective model.

Today, the different, pragmatist, new "emotional experiences" which are promised to the consumer by the product/services have primary importance for the consumers. The arguments "Love with your logic, select with your feelings" and in line with this "Now the way offeelings and logic is the same" expressed in the campaigns which are carried out for long term for Alfa GT by Alfa Romeo have a principle value in terms of the emotional message usage in the advertisements. The emotional messages in the advertisements are main redirectors at the stage of feeling among these stages. In most cases, feeling is the most appropriate tool in order to realize the persuasion activities and the most fundamental common ground of the people. In 
the process of influence of the advertisements, it is aimed to form different feelings concerning the related brand in the potential target audience and to establish an emotional bond between the consumer and the brand which is the object of the advertisement. This could be such an exaggerating situation that, a perfume could be equalized with exoticism, a GSM company could be equalized with reuniting, a credit card could be equalized with freedom and a detergent could be equalized with the "beauty of dirt". The more an advertiser knows the people and their feelings, the easier he could reach them and with higher influence.

The emotional approach towards the consumer acts from the approach that the consumers establish various relationships between the positive and negative feelings while evaluating the advertisement messages of the consumers. Another characteristic of such emotional messages is that they become effective also at the cognitive stage by associating the previous beautiful experiences by the messages in particular. These mentioned beautiful experiences are transferred into the product as emotions. Also, the related consumers are required to have these experiences most of the times. The imagination of the consumer who is required to establish sympathetic relationship on the experiences of the others is activated (Mitchell \& Olson, 1981, p. 31). The advertisers who act on the positive and negative emotional messages aim at directing the consumer preferences to the advertisement object product or service without ignoring the rationality. The emotional messages indicate the experimental side of the consumption. The creators of the messages aim at establishing an emotional relationship and a sensual connection between the customer and the product. While the competitive products are getting standardized, the brands which are already feelings are shaped in different meanings in order to address to the feelings of the consumers by the advertisers. In actual situation, the advertisers want the brands to behave as live creatures and make efforts in order to realize some emotional associations in the minds of the consumers by the brands. The marketing which left the productoriented and sale-oriented approaches is being performed with much more modern methods beginning from the last half of the previous century. The consumer became increasingly important within the modern marketing approach. The today's consumer performs the purchasing behavior by means of examining and with a certain consistency. The consumer does not consider being good of the product and the service sufficient, and at the same time, they want them look good as well. As a result of the decreased differences between the products with the modernization of the production in particular, the emotional perception of the products 
become even more important than the product itself. With its broadest meaning, the commodity aesthetics, emotional perception of the commodity and the perception of the usage value are separated from the object itself. The emotional perception, that is to say appearance, has become increasingly more important than the commodity itself (Haug, 1997, p. 24). In accordance with this fact, the advertisers attach a great importance on using the emotional messages for the purpose of ensuring the purchasing behavior.

All of these facts have to be associated with the advertisement object and the messages should be made more persuasive. The advertisement reader/spectator should read the feeling transmitted completely and should establish connection with the product. While transmitting the feeling, as much as possible, the balance should be established by means of rationalist messages (Anholt, 2003, p. 137-138). In the event the attitudes towards the product or service are at the low level in the target audience, the emotional messages have a particular importance in terms of formation of the necessary attitudes. It could be possible to realize the cognitive, emotional and behavioral elements of the attitude in the target audience by means of effective usage of these message strategies only. When we look at this fact in general meaning, what is important is that the brand communication which establishes an emotional bond with the consumer rather than making emphasis on more rational product or service while forming the advertisement message.

\section{Research: A Thematic Content Analysis Concerning the Message Repertory of the TV Commercials directed at the Young Target Audience}

An examination is performed on the commercials, for the purpose of revealing the emotional message contents of the TV commercials of the products directed at the young people. The definition of the conceptual meaning of the commercials examined is performed, in other words, the data collected are encoded. Following this stage, starting from the codes which appeared at the first stage, the themes which can explain the data in general level and collect the codes under certain categories are found. To this end, first of all the codes are got together and then examined and the common points are tried to be found. This is a thematic encoding process in some respect. As a result of the detailed encoding at the first stage and the thematic encoding at the second stage, a system is formed in the research. After this stage, the data obtained according to this system are arranged and the related data are defined and interpreted according to certain findings. At this final stage, the explanations concerning the importance of the results obtained 
are performed to acquire meanings for the data and to explain the relationships between the findings, to establish the cause-result relationships and to obtain some results from the findings. The following meanings are put on the concepts which are used in the analysis in accordance with this explanation:

1. Product category: White goods, brown goods, automobile/by-industry, electronic products, cleaning materials, flooring/curtain, cigarette/alcoholic drinks, shoes/bags, textile products, foodstuff, bank/insurance, transportation, medicine and corporate advertisements as the product groups which the advertisements belong.

2. Young people representations: In the research, visual appearance or voice element or other verbal elements such as writing in which the young people are represented.

\section{Research Methodology: Content Analysis}

This research is among the descriptive-conceptual researches. With this research, it is tried to define under which categories the products directed at the young people in Turkey are realized with various dimensions. The method which is selected for the research is the content analysis which is a method which is frequently used in the mass communication researches. The research method which is performed as directed at the content of the message transmitted in a positivist science approach is called the content analysis. The content analysis is quantitative and it takes up the visible fact and it carries the claim of objectivity because it is systematic. It is a widely used method in the researches on the subject of the target audience categories such as sex, age in the media. The fundamental purpose of the content analysis is to convert the verbal/written and other materials into digital data. This analysis could be also defined as analyzing and converting the written, verbal text or symbol into figures and to make comments on these figures, in other words, to convert the figures into words again. The process which is performed basically in the content analysis is to get together similar data in the frame of the certain concepts and themes and to arrange and interpret them to be understood by the reader. Before examining the stages of the content analysis, it is necessary to define the terms used. In addition to this, an inference should be made from the messages in the content analysis. In this respect, in the analysis which we will perform, it is aimed to count the frequency of the morphological elements in the texts which we will examine. Thus, we aim to see the elements which are frequently used on the way of being persuasive by the advertisement language in the manner to cover our research purposes. It is compulsory to divide the message into some categories in 
order to make the content analysis productive and to determine certain units (Bilgin, 2000, p. $63)$.

\section{Sample Method and Restrictions of the Research}

The field of the research is composed of the television commercials. The sample of the television commercials is formed by means of selecting 4 of the national and thematic television channels randomly. According to this, ATV, Kanal D, Haberturk TV and NTV Spor are watched for seven days between the hours 20.00 and 23.00 which are qualified as the primetime hours, and then the commercials encountered are analyzed according to the abovestated elements. Total 2482 commercials are watched from 9 different sectors in the mentioned examination. Four TV channels are included because of the time and cost restrictions in the study. Among them, ATV and Kanal D are national TV channels, and Haberturk TV is a national thematic new channel and NTV Spor is a national thematic sports channel.

\section{Purpose of the Research}

In the frame of the purpose and model determined in the research, the research questions are defined as follows:

Q1: How was the distribution of the entire advertisement network in the sample?

Q2: Under which product categories the advertisements directed at the young people are performed?

Q3: Under which categories the emotional messages directed at the young people could be collected in the products directed at the young people?

Q4: What are the most frequently repeated advertisements among all of the advertisements?

Q5: What are the most frequently repeated themes among the advertisement messages directed at the young people?

Q6: What comments could be performed about the messages directed at the young people on the message categories determined?

\section{Findings}

The breakdown of the commercials between the hours 20.00 and 23.00 which are qualified as the prime-time hours in ATV, Kanal D, Haberturk TV and NTV Spor television channels realized as follows. Total 2482 commercials are watched from 9 different sectors in the 
mentioned examination. The following results are reached relating to the distribution of these commercials:

\section{Data in terms of Frequency Analysis}

The analysis sets forth the distribution of all of the commercials watched in the expressed time slice to the channels and to the total; the distribution of only the youth commercials to the channels and to the total, both individually and cumulatively. The analysis is a frequency analysis, and the findings are given by figure and proportionally. The total number of commercial watched realized as 2482 in 4 channels. According to the distribution to the channels, Kanal D forms $31.99 \%$ of all of the commercials with 672 commercials and this brings the channel to the channel which makes maximum number of commercials. Haberturk is at the last line with 461 commercials and $18.57 \%$ rate. ATV has 672 commercials and $27.07 \%$ rate and NTV has 555 commercials and $22.36 \%$ rate.

\section{Data in terms of the Product Groups}

The analysis gave the sectors which include the messages directed at the youth according to the frequency and channels and distribution according to the number of releases among all of the television channels watched. There is proportional expression of the same analysis. According to this, the food and beverage category became the sector which gives highest number of messages as directed at the young people among all of the sectors, with total 425 messages and $35.65 \%$ rate. It is followed by the telecommunication sector with 405 commercials and $33.95 \%$ rate and cosmetics and personal care sector with 187 commercials. Its percentage expression realized as $15.67 \%$. Apart from that, it is followed by the media-communication-cinemaentertainment, technology, automotive and retailing sectors respectively. Banking/insurance and dressing sector is represented with 1 commercial only in the entire sample. When we examine the same table in terms of the single advertisements, the food and beverage sector took part in the first line again with $44.35 \%$ rate. The cosmetics and personal care products are the second most frequently broadcast commercials with $22.58 \%$ rate. The telecommunication sector commercial is in the third line with $16.13 \%$. It is followed by the mediacommunicationcinema-entertainment by $5.65 \%$ and technology by $4.84 \%$. In terms of the single commercials, the retail sector is also represented with 1 single commercial like banking / insurance and dressing commercial. Finally, when we look at the data in terms of the channels which broadcast the commercials, ATV became first with 414 commercials, Kanal D became 
second with 361 commercials, NTV Spor became third with 247 commercials and Haberturk TV became the last with 147 commercials. When we look at the youth category only, Kanal D became first with 216 commercials and 59.83\% rate and ATV became second with 149 commercials and $35.99 \%$ rate.

\section{Data in terms of the Themes Presented to the Young People}

In this chapter in which we look at the emotional message themes arranged as directed at the young people, 10 different themes are determined in the content analysis performed: Being privileged, belonging to a place, group or object, sexual messages, insanity, change, different identity, performance increase, increased popularity and promise for health. The "difference" theme is first with 390 commercials, "being privileged" is second with 220 commercials, "increased popularity" is third with 168 commercials and insanity is fourth with 103 commercials. These four themes are followed by "increased performance", "sexual messages", "identity", "change" and belonging to a place, group or object and promise for health respectively. "Promise for health" takes part in the last place with 18 commercials. When it is looked at the percentage rates, "difference" has $32.69 \%$ rate in all commercials category and $40.32 \%$ in single commercials. "Being privileged" theme takes part with $18.32 \%$ in all commercials category and $15.32 \%$ in single commercials. "Increased popularity" realized with $14.08 \%$ in all commercials category and $12.90 \%$ in single commercials. "Insanity" theme is $8.63 \%$ in all commercials category and $7.26 \%$ in single commercials. "Promise for health" takes part in the last line of the list with $1.51 \%$ rate. The rate of this theme in the single commercials realized as $1.61 \%$. When we look at the distribution of the emotional message themes to the channels, the theme of "being privileged" became the most frequently broadcast commercial in this channel proportionally with $42.11 \%$ in Haberturk. The theme of "difference" became the most frequently broadcast theme in with $47.09 \%$ in Kanal D. The theme of difference became the most frequently broadcast theme similarly in ATV and NTV Spor. They realized as $29.23 \%$ and $31.98 \%$ respectively.

\section{Data Concerning the Most Frequently Repeated Commercials and Themes}

The most frequently repeated advertisement message in all of the sectors became TtNet commercial with 98 commercials. The commercial with which the difference emphasis is made as directed at the young people is the most frequently repeated commercial at the level of all channels. 


\section{Conclusion}

It is seen in the research that youth is a very favorite category today for the advertisers and 1193 commercials which give messages for the young people are encountered among 2482 commercials watched in total. And this forms $48 \%$ of all of the commercials broadcasted. This sets forth that there is a message for the young people nearly in one of two commercials. It is seen that the weight is with the food and beverages sector with $35.62 \%$ in the messages directed at the young people. It is followed by the cosmetic and personal care category with $15.67 \%$. The most frequently repeated commercial among all of the commercials became TTnet commercial which emphasizes the difference theme with total 9 frequencies in total. Turkcell (roaming power) commercial took part in the second line with 83 commercials. Haberturk commercial which is a commercial which emphasizes to be different takes place in the third line.

After these numerical data, what should be said is that what is presented to the consumer in the commercials is not the product and product benefit only. The advertisement meets the consumer by means of promising a lifestyle. The advertisement is a new life to be reached thanks to the product presented. The advertisement is an important fact which influences the cultural and social life of the people and reflects the same in the modern life. The commercials are not "unseen message carries" at any time and irrespective of the form of advertisement, what is important is the meaning in its content. When we look at Turkey which is a Western type capitalist society, the world of the young people accommodates difficulties, hopefulness and pessimism beyond the accustomed clichés and stereotypes. The most important problem of the young people is to express themselves. The young people are making efforts not only to express their identities but also to form their lifestyles. We see that the commercials also mention these gaps of the young people. Change, identity, difference and belonging are among the themes which illustrate this argument. According to the results of the research, while it is seen that these messages mention the theme of difference with $32.69 \%$, this theme is followed by being privileged with $18.44 \%$ and increased popularity with $14.08 \%$. Belonging to a place, group or object, sexual messages, insanity, change, identity, promise for health, increased performance and increased popularity have become the other message themes which are presented to the Turkish youth in the TV commercials. It is seen that a support role which will develop their feeling of capability is adopted while making marketing to the young people in the commercials, 
and the commercials are used as intermediary for this process. The brands deepen the relationship to be established with the young people with these emotional messages. It is seen in the research that the commercials show the young people with this approach as follows:

- The young people could exhibit their capabilities. It is considered that it is associated with the theme of being liked and appreciated.

- It is seen that the young people express themselves through the products and services and in this manner they cause change / conversion.

- It is revealed in the content analysis performed that the young people are seen together with what looks like them through the products ad services and they are shown as a valuable member of that group.

- It is understood that the young people try to establish connection continuously with what they like through the usage of the products and services.

- We see in the research that the young people mention to share the popularity, "that day", attitudes, approaches, tastes, jokes, relationships and feelings and in short the common values which make them young.

The young people of the day who were born in the internet age is a group which is should be deeply examined which is open to the new and different things but with lower brand loyalty, living fast and making consumption and also influences the consumption of their families and attaches a great importance on communication. The young people, who are looking for an identity, an experience, an emotional bond and relationship/communication which will be enabled by using that brand together with the functionality in their brand preferences; are examined with its Turkey sample in this research. An identifying study is carried out with Turkey sample which is a newly developing and dynamic market. The following studies could be carried out on examining the influence which is left on the young people by these themes. An intercultural study will be ideal in terms of comparing Turkey with another country in the global marketing age. 


\section{References}

Anholt, S. (2003). Global Markaların Yerel Çuvallamaları, (çev:Gonca Canan), İstanbul: MediaCat Yayınları.

Baldwin, H. (1989). How To Create Effective TV Commercials, Second Edition, NTC Publishing Group.

Bilgin, N. (2000). İçerik Analizi. İzmir: Ege Üniversitesi Edebiyat Fakültesi Yayınları.

Brackett, L. K., \& Carr, B. N. (2001). Cyberspace advertising vs. other media: consumer vs. mature student attitudes. J. Advertising Res., 41(5), 23-32.

Cankaya, S. (2009). Facebook istatistikleri. Retrieved on February 02 from http://blog.mindshareinteraction.net/facebook-istatistikleri

Cappo, J. (2003). The future of advertising: new media, new clients, new consumers in the posttelevision age. New York: McGraw Hill.

Collins, R. L., Ellickson, P. L., McCaffrey, D., \& Hambarsoomians, K. (2007). Early Adolescent Exposure to Alcohol Advertising and its Relationship to Underage Drinking. Journal of Adolescent Health, 40(6), 527-534.

Fischer, E., \& Arnold, S. (1994). Sex, Gender Identity, Gender Role Attitudes and Consumer Behavior. Psychology and Marketing, 11(2), 163-182.

Godes, D., \& Mayzlin, D. (2004). Using Online Conversations to Study Word of Mouth Communication. Marketing Science, 23(4), 545-560.

Haug, F. W. (1997). Meta Estetiğin Eleştirisi: Kapitalist Toplumda Görüntü, Cinsellik ve Reklam. Çev. Ayşe Gül. İstanbul: Spartaküs Yayınları.

Jernigan, D., Ostroff, J., \& Ross, C. (2005). Alcohol Advertising and Youth: A Measured Approach. Journal of Public Health Policy, 26(2005), 312-325.

Laskey, A. H., Day, E., \& Crask, R. M. (1989). Typology of Main Message Strategies for Television Commercials. Journal of Advertising, 18(1).

Leiss, W., Kline, S., \& Jhally, S. (1990). Social communication in advertising. Scarborough, Ontario: Nelson Canada.

Mitchell, A. A., \& Olson, J. C. (1981). Are Product Attribute Beliefs the Only Mediator of Advertising Effects on Brand Attitude? Journal of Marketing Research, 18(3), 318332.

Ogilvy, D. (1983). Ogilvy On Advertising. New York: Vintage Books. 
Pasch, K. E., Komro, K. A. , Perry, C. L., Hearst, M. O., \& Farbakhsh, K. (2007). Outdoor Alcohol Advertising Near Schools: What Does It Advertise and How Is It Related to Intentions and Use of Alcohol Among Young Adolescents? Journal of Studies on Alcohol and Drugs, 68(4), 587-596.

Rago, R. (1989). Finding Magic: "Cognitive Aspects of Mood and Emotion in Advertising. Review of Business, 14, 9-10.

Rutherford, P. (2000). Yeni İkonolar; “Televizyonda Reklam Sanatı”. Çev. Mustafa K. Gerçeker. İstanbul: YKY.

Schmit, B. H. (1999). Experiential marketing: How to Get Customers to Sense, Feel, Think, Act, and Relate to Your Company and Brands. New York: Free Press.

Schroeder, J. E. (1998). Consuming sexuality: A case study of identity marketing. In E. Fischer \& D. Wardlow (Ed.) Gender, marketing and consumer behavior. San Francisco: San Francisco State University.

Stacy, A. W., Zogg, J. B., Unger, J. B., \& Dent., C. W. (2004). Exposure to Televised Alcohol Ads and Subsequent Adolescent Alcohol Use. American Journal of Health Behavior, 28(6), 498-509.

Spero, I., \& Stone, M. (2004). Agents of change: how young consumers are changing the world of marketing. Qualitative Market Research: Int. J., 7(2), 153.

Thiyagu, A. (2008). Analysis of Television Commercial Directed for Young Adults - ELM and Social Identification Perspective (July 22, 2008). Retrieved from http://ssrn.com/abstract=1168047

Vassaf, G. (1997). Cennetin Dibi (4. ed.). Istanbul: Ayrıntı Yayınları.

Williamson, J. (2000). Reklamların Dili; "Reklamlarda Anlam ve İdeoloji.” Çev., Ahmet Fethi. İstanbul: Ütopya Yayınları, 2000.

Nielsen, A. C. (2005). Herkesin Merak Ettiği Gençleri Araştırdı: Kararı Gençler Veriyor. Retrieved from http://www.iaatram.com/downloads/Genclik\%20Arastirmasi.doc EGITISIM. (2009). Gençlere göre markaların kişisel özellikleri araştırması. Retrieved from http://www.egitisim-blog.com/genclere-gore-markalarinkisisel-ozellikleri-arastirmasi TÜIK. (2000). Nüfus Sayım1. Retrieved from http://tuikapp.tuik.gov.tr/nufusapp/idari.zul EUROSTAT. (2005). Retrieved from http://epp.eurostat.ec.europa.eu/portal/page/portal/ eurostat/home/ 